\title{
Harmonizing Ideological Tension in the Development of the ASEAN Law
}

\section{Ida Bagus Wyasa Putra*}

There have been at least twenty Summits among the ASEAN countries. They adopted about twenty basic legal documents. All these are dedicated to realizing the ambitious dream of the ASEAN countries to be developed. However, the facts went opposite. ASEAN cooperation stays slow and reaches a very narrow target. Most ASEAN people feel bored and hopeless over the state of cooperation. The slow and narrow cooperation have disposed the cooperation into a downfall image such as a fiction, or even a utopian. The downfall image could make cooperation even slower or end it altogether, as it commonly drives the belief of the people from trust to distrust and believing into disbelieving. The gap between the 'sollen' and the 'sein' in the cooperation shows a strong influence of undetectable causes. This article applies a law and ideological approach in searching and analyzing the cause of slowness of performance of the cooperation.

\section{Introduction}

The ideological aspect of law has been studied for hundreds of years, although it was sometimes ignored by legal scholars. Hans Kelsen (1881-1973), ${ }^{1}$ a leading legal philosopher, representing the 'Wiener Schule,' through his "Pure Theory of Law (Reine Rechtslehre)," 2 has strictly secured law from any of its non-normative aspects, such as

* Head of Domestic and International Cooperation Board, Faculty of Law at Udayana University, Bali, Indonesia. LL.B.(Udayana Univ.), LL.M.(Padjadjaran Univ.), Ph.D.(Brawijaya Univ.). The author may be contacted: wyasp@yahoo.com / Faculty of Law, Udayana University, Jalan Bali No. 1, Denpasar, Bali, Indonesia. Address: Faculty of Law at Udayana University, Л. Bali No. 1 Denpasar-Bali-Indonesia.

1 Hans Kelsen, born in Prague in 1881, was a legendary legal scholar. For his life and thoughts, see Hans Kelsen, available at http://www.unostamps.nl/person_kelsen.htm (last visited on Nov. 1, 2012)

2 For details on Reine Rechtslehre, see H. Kelsen, Introduction to the Problems of Legal Theory 7 (1966); General Theory of LaW and State 39, 61 (1971); and Introduction to the Problems of Legal Theory 7 (1966). Regarding Reine Rechtslehre see L. Rasjidi \& I. Wyasa, Hukum Sebagai Suatu Sistem (LaW as a System) 1 (2012); J. Stone, The Province and Function of LaW: LaW as Logic Justice and Social Control $91-92$ (1950); H. Hawton, Philosophy 
history, ethic, ideology, politics, economy, social, culture, etc. He defined 'law' as merely a norm. ${ }^{3}$ Since then, the "pure theory of law" predominantly has been influencing contemporary legal thinking and most legal scholars define law from the Kelsenian perspective. The followers of this theory strictly view law as a norm and limit their scientific work to the normative approach of law. They mostly study all kinds of normative problems regarding conflict, which they perform in the validity, consistency and coherency test of norm. 4 They do not deal with the problems of substance and function of law. That is why some jurists strongly criticize Kelsen's theory, especially when the theory suffers the functions of law in performing its actual task in social life. 5

The primary task of law is supposed to be to control social changes. 6 How to realize it, then? This practical question attracted some legal scholars to bring back the complete nature of jurisprudence where the 'sein' shall be open to its empirical and objective facts of law in the actual social life and shall not be surrendered solely to any closed rational or analytical approach. ${ }^{7}$

Law is a transformation of ideology, not only under the idealistic definition by Karl Marx, 8 but also within its actual existence in the community life. ${ }^{9}$ The community's value and interest which is driven from its ideology or its actual value and interest shall be in conformity with the community's ideology. Law is a result of the response or articulation of the community's expectations by the law-makers. Hence, the function of law needs to be recovered by means of recovering its content. 10

ASEAN law reflects a great harmony of values, interests, and needs of the ASEAN member countries. 11 However, it has not supported the actualization of the ASEAN

for Pleasure: An Adventure In Ideas 36 (1956); and R. Pound, Interpretations of Legal History 1 (1986).

3 J. Harris, LaW and Legal Science: An InquiRy into the Concepts Legal Rule and Legal System 34 (1982). A norm is a generally accepted standard of social behavior. Kelsen uses the term in his definition of law as "the primary norm that stipulated the sanction.” See Zang Wan Hong \& Guo Yi, JuRisprudence 20 (2003).

4 B. Brouwer et al, Cohenrence and Conflict in Law 17, 39 (1992). Cf. A. Peczenik, A Theory of Legal Doctrine, 14 RATIO JURIS 84 (2001).

5 McDougal criticizes Kelsen's theory as lacking the capacity to explain the actual existence of law as a continuing process of authoritative decisions. See M. McDougal, Law as a Process of Decision: A policy-Oriented Approach to Legal Study, 1 Natural LaW STUdY 58 (1956). For details on the criticism against the Kelsen's jurisprudence, see J. Priban, Legal Fictions and the Problem of Scientific Legitimation, 16 RATIO JURIS 20 (2003); J. Otto, W. Stoter \& J. Arnscheidt, Using Legislative Theory to Improve Law and Development Projects, 2 JuRnal Regel Mat AFL. 4 (2004); H. Chand, Modern JuRisprudence 105 (1994); and H. Kelsen, Introduction to the Problems of Legal Theory xvii (1966).

6 Pound, supra note 2 , at 1.

7 Id. See also Hawton, supra note 2, at 36; A. WhiteHEAd, ScIENCE AND THE Modern WorLd 200 (1926).

8 K. Marx defines ideology as any set of political illusion that has been produced by the social experience of a class. See L. SARgent, Contemporary Political Ideologies 3 (1981).

9 Id.

10 Y. Dror, Venture in Policy ScIences 169 (1977).

11 The harmony among the ASEAN countries has been repeatedly expressed in many ASEAN legal instruments. See, e.g., ASEAN (Bangkok) Declaration 1967, ASEAN Concord 1976, Agreement on ASEAN Preferential Trading 
mission. The serious problems of poverty, health, education, environment, and welfare in the ASEAN gives ASEAN cooperation a bad image, making it slow and useless.12 The gap between the law and existing social life of the ASEAN people shows a serious, persistent, silent, and fundamental problem of the ASEAN law-making process which is rooted in the problem of ideology. Although the conflict of values and interests are usually taken into account and solved at every step of the law-making process, it is differently implemented in the real world. The actual formulation of values and interests are usually hidden in the expressed values, and work through its own silent, persistent, and fundamental path. Under this scheme, the hidden values and interests would bother the normal work of the expressed value and interest. This way of working is not visible but would influence on the performance of law. 13

The smooth functioning of law would indicate the agreement between expressed values and interests and hidden values and interests, while the 'slowness' and malfunction of law would indicate the opposite condition. The 'slowness' of ASEAN cooperation in the social life of the ASEAN people shows a close relationship between the theory of the influence of hidden values and interests against the expressed value and interests which is laid down in the ASEAN law. It is necessary to trace out the existence of these hidden values and interest in order to remove any obstacle disturbing the role of the ASEAN law.14

The main purpose of this article is to demonstrate the existence of the ASEAN ideologies followed by the way they work, the problems caused by them with regard to the function of ASEAN law, and finally to propose solutions. This paper is composed of eights parts including introduction and conclusion. To start with, Part two will introduce the ideologies in ASEAN, while Part three will investigate the work of the ideologies. Then, Part four will examine the ideological tension in the ASEAN lawmaking process followed by evaluation of ideological influence in Part five. Next, Part six will propose an approach for legislation and Part seven will discuss ways to

Arrangements 1977; and The Preamble of the Treaty of Amity and Cooperation in Southeast Asia 1976.

12 Cf. A. Asra, G. Estrada \& E. Pernia, ASEAN Economic Community: Implications for Poverty Reduction in Southeast Asia, in Roadmap to an AsEan Economic Community 220-221 (D. Hew ed. 2005). See L. Corner, Rural Development and Poverty Alleviation in ASEAN: A Gender Perspective, paper presented to the ASEAN Senior Officials Meeting on Poverty Alleviation and Rural Development, Kuala Lumpur, Oct. 27, 1997, at 1, available at http://www1.aucegypt.edu/src/engendering/Documents/Engendering_Macroeconomics/ASEANpoverty.pdf (last visited on Nov. 1, 2012). See also M. McDougal \& W. Reisman, International Law in Policy-Oriented Perspective, in The Structure and Process of International LaW: Essays in Legal Philosophy Doctrine and Theory 104 (R. Macdonald \& D. Johnston eds., 1983).

13 Ida Bagus Wyasa Putra, The Function of Law in Regulating Tourism as a Trade in Services 289 (May 15, 2010) (unpublished Ph.D. dissertation, University of Brawijaya, Indonesia).

14 Id. 
harmonize values and strengthen the power of law to overcome the ideological tension in the ASEAN. 15

\section{Ideologies in the ASEAN}

Ideology is unique and may be expressed through truth or fiction. It is loaded by a set of interests which is constructed above the needs of the owner and expressed in a set of values. Most people question whether ideology is a set of values, needs, or interests. In fact, ideology is a formulation of needs, interests, and values of the community owner. Ideology is an honest response of collective human beings to its environment.16 The human brain articulates the expectation of its surroundings; they can be in the form of support or pressure, which forces them to choose the way they shall live and behave in relation to its social and physical environment. The judgment of those needs and interests is called 'values.' When those sets of values are held under a strong belief, it is called 'ideology.' 17

Ideology is a value or belief that is accepted as fact or truth by some group. It provides the followers with a picture of the world both as it is and as it should be. It organizes the tremendous complexity of the world into something fairly simple and understandable. Karl Marx judged it as a 'political illusion' that had been produced by social experience of a class, 18 because of its intangible existence and utopian nature. However, ideology is not an illusion. It is an intangible fact which is transformed into any single value, theory, concept, principle, law, regulation, technique, procedure, devices, living instrument and equipment, lifestyle, etc. It may be used and controlled at any occasion in the life of human beings or another way based on three raw materials of ideology such as social and physical environment, human brain and sense, and vision of life.19

Meanwhile, State ideology may be reflected in its constitution, containing its historical, cultural, and environmental background. Simultaneously, ideology may be shaped in a set of ideal political visions of the State.

\footnotetext{
15 For approaches for legislation in relation of legislation with ideological content, see McDougal, supra note 5, at 56-57; W. Chambliss, On Lawmaking, in Making LaW, the STATE, the LaW, ANd STRUCTURE Contradiction (W. Chambliss \& M. Zatz eds., $5^{\text {th }}$ ed. 1993).

16 B. Russett, H. Stark \& D. Kinsella (EDS)., World Politics: The Menu For Choice 74 (3rd ed. 1989).

17 Cf. H. Suretsky, The Concept of Ideology and Its Applicability to Law and Literature Studies, 4 ALSA FoRUM 34 (1981).

18 Sargent, supra note 8.

19 Wyasa, supra note 13 , at 290.
} 
The ideologies of some of the ASEAN member States may be projected in the following Table.

Table II-1: The Ideologies of the ASEAN member States

\begin{tabular}{|c|c|c|c|}
\hline NO & State & Constitution & $\begin{array}{c}\text { The Marks / Shape / Formulation of } \\
\text { Ideology }\end{array}$ \\
\hline 1 & Indonesia & $\begin{array}{c}\text { Constitution } \\
1945\end{array}$ & $\begin{array}{l}\text { Belief in one Supreme God, just and civilized } \\
\text { humanity, unity of Indonesia, democracy guided } \\
\text { by inner wisdom of unanimous decision-making, } \\
\text { and social justice for the people of Indonesia. } 20\end{array}$ \\
\hline 2 & Malaysia & $\begin{array}{c}\text { Constitution } \\
1957\end{array}$ & $\begin{array}{l}\text { Federal state, Islamic State, Parliamentary, } \\
\text { Ministry under Yang di-Pertuan Agong, } \\
\text { Constitutional supremacy, fundamental liberties } \\
\text { of citizens including freedom of religion } \\
\text { guaranteed by the State, rights to property, } \\
\text { citizenship limited to the genuine Malaysian and } \\
\text { tough naturalization, State's competence to act as } \\
\text { private person and to enter into contract, State's } \\
\text { status to sue or be sued, democracy, State and } \\
\text { Federal State sponsored public services. }{ }^{21}\end{array}$ \\
\hline 3 & $\begin{array}{c}\text { The } \\
\text { Philippines }\end{array}$ & $\begin{array}{c}\text { Constitution } \\
1987\end{array}$ & $\begin{array}{l}\text { State Sovereignty, belief in Almighty God, just } \\
\text { and humane society, Government that embodies } \\
\text { people's ideals and aspirations, promotes the } \\
\text { common good, conserves and develops the } \\
\text { patrimony, and secures to their selves and } \\
\text { posterity independence and democracy under } \\
\text { the rule of law and a regime of truth, justice, } \\
\text { freedom, love, equality, and peace, do ordain and } \\
\text { promulgate the Constitution, democratic } \\
\text { Republic, independent foreign policy, full respect } \\
\text { of human rights, including indigenous } \\
\text { community, open citizenship.22 }\end{array}$ \\
\hline
\end{tabular}

20 INDONESIAN CONST., available at http://www.embasyofindonesia.org/about/pdf/IndonesianConstitution.pdf (last visited on Nov. 1, 2012).

21 MaLaYsIAN CONST., available at http://www.confider.richmond.edu/admin/docs/malaysia.pdf last visited on Nov. 1, 2012).

22 PHILIPPINE ConST. pmbl, available at http://www.lawphil.net/consti/cons1987.htm (last visited on Nov. 1, 2012) 


\begin{tabular}{|c|c|l|}
\hline Sinagpore & $\begin{array}{l}\text { Constitution } \\
1963\end{array}$ & $\begin{array}{l}\text { Republic, national state, full/absolute sovereignty, } \\
\text { independent nation, presidential, constitution } \\
\text { supremacy, mutual international cooperation, } \\
\text { administration of people's power through } \\
\text { parliament, full protection of citizen's Human } \\
\text { Rights, rights to religion, state authority to set up } \\
\text { government companies under the State budget, } \\
\text { competence of government to act as a person in } \\
\text { private affair, State's status to sue or may be } \\
\text { sued, legislature consist of the President and the } \\
\text { Parliament, judicial power vested in supreme } \\
\text { court, right of citizens to public services, open } \\
\text { citizen membership, Commonwealth back up.23 }\end{array}$ \\
\hline 5 & Thailand & Constitution \\
1997 & $\begin{array}{l}\text { Kingdom based on constitution, democratic, } \\
\text { bicameral, full respect of human rights, unitary and } \\
\text { decentralized State.24 }\end{array}$ \\
\hline
\end{tabular}

Source: Compiled by the author

These ASEAN States share a common nature on each of their ideology in their Constitutions. All State ideologies put a similar emphasis on religion, humanity, democracy, and social justice. Nevertheless, these similarities may have contributed to setting up agreement concerning common issues on the ASEAN cooperation, 25 and may not draw up the real needs and interests of the nations.

Similarly, the ASEAN countries share similar cultural but different environment, history, and political backgrounds. Such diversity between the ASEAN States produces different ways of thinking, attitudes, and behavior. The different natural environment, geographical position, size, and natural resources have also widened up the gap between needs and interests of the ASEAN countries. Each State has thus faced difficulties on covering/bridging the gap between their domestic and common needs and interest. The ASEAN countries have been ambitiously and directly moving toward the ASEAN common market ignoring the very fundamental principle of liberalization and recovering for the asymmetric economic condition of each member States. 26 Especially, the ASEAN common market is expected to expand people's economic 
capacity to access the free market of ASEAN.

The natural environment and historical background of the ASEAN countries have transformed each ASEAN country into both idealistic and pragmatic ideologies at the same time. Under the ideology of Pancasila, e.g., Indonesia would pay more attention to the actual economic condition and bring more protection to its people. 27 In fact, Indonesia has restricted its market access to global products, which created undue pressure and suffering to its people. Singapore has adopted communalism, meritocracy and pragmatism, which led Singapore to attach strong domestic interest. The case is the same in Thailand, Malaysia, and other ASEAN countries which make them stay inside their domestic interests.

The ASEAN cooperation has also suffered more from globalization which brings more manipulated values to the ASEAN community. Globalization is not similar to liberalization. Liberalization is based on Adam Smith's liberalization ideology that works within the two pillars of basic values of liberal trade: empowering the weak and increasing the free movement of production factors and products. 28 Globalization is based on manipulated liberalism; it is allegedly due to neo-liberalism. ${ }^{29}$ However, it is actually neo-capitalism, called philanthrocapitalism, which proposes the possession and control of all profitable economics assets of the world. ${ }^{30}$ It begins with working through a concept of universal society based on universalism which impels helping minorities through financial and non-financial aid. In contrast, meanwhile, universalism ignored State sovereignty, and finally expected economic resources and market access. 31 This uses all instruments and institutions, such as science, technologies, concepts, policies, etc. Herewith, ideological skill is necessary to manage the work. Otherwise, it would not only slow down the work of ASEAN cooperation, but also dictate or even drop it.

27 According to Sukarno, the Indonesian socio-democracy is one which shall be based on or rely on the actual life of Indonesian people. This principle of ideology shall apply to Indonesia's concept of economic development. Wyasa, supra note 13 , at 227 .

28 A. Smith, Experts from The Wealth of Nations, in InTERnational Political Economy: STATe-Market Relations in A Changing Global Order 33 (C. Goddard, P. Cronin \& K. Dash eds. 2003). See also M. Skousen, Teori-Teori EKonomi Modern(Theory of Modern Economics) 21, 28-29 (2006).

29 R. Gilpin, Three Ideologies of Political Economy, in International Political Economy: A Reader 12-13 (K. Stiles \& T. Akaha eds., 1991). See also the same author, The Nature of Political Economy, in Goddard, Cronin \& Dash (eds.), id. at 30 .

30 M. Bishop, Economics 242 (2009). Cf. A. Callinicos, Globalization, Imperialism and the Capitalist World System, in GLobalization Theory: Approaches And Controversies 68 (D. Held \& A. McGrew eds. 2007).

31 See Truman's Inaugural Address (Jan. 20, 1949), available at http://www.trumanlibrary.org/whistlestop/50yr_archive/ inagural20jan1949.htm (last visited on Nov. 1, 2012). 


\section{The Work of Ideology}

Ideology works through transformation. 32 It transforms itself under or out of consciousness, with or without knowledge, with or without skill, under or without planning in the work of human beings. Ideological transformations under consciousness, with knowledge, skill, and planning are called planned or programmed transformation of ideology, while its opposite side is called a natural transformation of ideology. Both are dangerous for human life. The conscious transformation of ideology may interfere with the human mind. The mind of human beings, according to Roscoe Pound, is a density of interest, 33 which, according to Marx, comes to the density of desire. Marx explains that it forces human beings to enslave the others. 34 Then, the pure and neutral nature of ideology might influence and disperse into personal or group interests. Meanwhile, the unconscious transformation of ideology may influence human life through its silent, persistent, and fundamental effects. These two kinds of threats of the transformation of ideology work through various shapes of ideology, such as values, cultures, traditions, science, theories, concepts, principles, law, rules, procedures, techniques, technologies, devices, instruments, equipments, life styles, system, method, etc. Hence, it is difficult for human beings to recognize the existence of ideology and to control the detrimental effects of its work.

The differences between the expressed and the hidden values of the ASEAN and global ideologies show that ASEAN cooperation needs an additional approach to its cooperation that enables the ASEAN countries to touch the fundamental problem of ASEAN cooperation. The legal and ideological approach would be suitable for supporting these needs.

\section{Ideological Tension in the ASEAN Law-Making Process}

Ideological tension in the ASEAN law-making process does not exist on the table of negotiation, but in the back stage. All ASEAN laws and regulations, including the outcomes of the twenty ASEAN Summits, expressed an excellent proper work of

\footnotetext{
Wyasa, supra note 13 , at 289. See also supra note 16 , at 18.

Chand, supra note 5, at 196-197.

Skousen, supra note 28 , at 175 .
} 
negotiation in administering the ASEAN ideological tension.35 The outcomes of major ASEAN Summits are shared in the Table below.

Table IV-1: The Outcomes of Major ASEAN Summits

\begin{tabular}{|c|c|c|c|c|}
\hline $\begin{array}{c}\text { List of } \\
\text { Summit }\end{array}$ & Date & Venue & Outcomes & Contents \\
\hline $1^{\mathrm{st}}$ & $\begin{array}{c}\text { Feb. 23-24, } \\
1976\end{array}$ & $\begin{array}{c}\text { Bali, } \\
\text { Indonesia }\end{array}$ & $\begin{array}{l}\text { Treaty of } \\
\text { Amity and } \\
\text { Cooperation in } \\
\text { South East Asia }\end{array}$ & $\begin{array}{l}\text { Through this Summit ASEAN countries } \\
\text { expressed their readiness to develop fruitful } \\
\text { and mutually beneficial cooperation with } \\
\text { other countries of the region. } 36\end{array}$ \\
\hline $9^{\text {th }}$ & $\begin{array}{c}\text { Oct. 7-8, } \\
1993\end{array}$ & $\begin{array}{c}\text { Bali, } \\
\text { Indonesia }\end{array}$ & Bali Concord II & $\begin{array}{l}\text { The Declaration mentions that the ASEAN } \\
\text { Community shall be set upon three pillars } \\
\text { such as political and security cooperation } \\
\text { economic cooperation, and socio-cultural } \\
\text { cooperation in order to ensure durable } \\
\text { peace, stability and shared prosperity in the } \\
\text { region. The free trade area is expected to be } \\
\text { established by } 2020.37\end{array}$ \\
\hline $11^{\text {th }}$ & $\begin{array}{c}\text { Dec. 12-14, } \\
2005\end{array}$ & $\begin{array}{l}\text { Kuala } \\
\text { Lumpur, } \\
\text { Malaysia }\end{array}$ & $\begin{array}{l}\text { Kuala Lumpur } \\
\text { Declaration on } \\
\text { the East Asia } \\
\text { Summit }\end{array}$ & $\begin{array}{l}\text { This Summit considered seven important } \\
\text { issues with regard to public health (the } \\
\text { wide and fast spread of bird flu), security } \\
\text { (southern Thailand conflict), democracy } \\
\text { (democracy in Myanmar), and economy } \\
\text { (crude oil prices fluctuation and poverty, } \\
\text { investment and trade), and the ASEAN } \\
\text { Charter. } 38\end{array}$ \\
\hline $12^{\text {th }}$ & $\begin{array}{c}\text { Jan. } 12-15, \\
2007\end{array}$ & $\begin{array}{c}\text { Cebu, } \\
\text { Philippines }\end{array}$ & $\begin{array}{l}\text { Cebu } \\
\text { Declaration on } \\
\text { East Asian } \\
\text { Energy Security }\end{array}$ & $\begin{array}{l}\text { The Summit adopted five agreements with } \\
\text { regard to continuance integration of } \\
\text { ASEAN enhancing political, economic and } \\
\text { social cooperation in the region, including } \\
\text { Cebu Declaration Towards Caring and }\end{array}$ \\
\hline
\end{tabular}

35 For details, see ASEAN SECRETARIAT, 10 YeArs ASEAN 9 (1978).

36 For details, see First ASEAN Summit, available at http://www.asean.org/news/item/the-first-asean-summit (last visited on Nov. 1, 2012).

37 For details, see Ninth ASEAN Summit, available at http://www.asean.org/news/item/the-ninth-asean-summit (last visited on Nov. 1, 2012)

38 For details, see Eleventh ASEAN Summit, available at http://www.asean.org/news/item/eleventh-asean-summitkuala-lumpur-12-14-december-2005 (last visited on Nov. 1, 2012) 


\begin{tabular}{|c|c|c|c|c|}
\hline & & & & $\begin{array}{l}\text { Sharing Community; Cebu Declaration on } \\
\text { the Blueprint of the ASEAN Charter; Cebu } \\
\text { Declaration on the Acceleration of the } \\
\text { Establishment of ASEAN Community by } \\
\text { 2015; ASEAN Declaration on the } \\
\text { Protection and Promotion of the Rights of } \\
\text { Migrant Workers; and ASEAN Convention } \\
\text { on Counter Terrorism. } 39\end{array}$ \\
\hline $13^{\text {th }}$ & $\begin{array}{c}\text { Nov. 18-22, } \\
2007\end{array}$ & Singapore & $\begin{array}{l}\text { The ASEAN } \\
\text { Leaders' } \\
\text { Declaration on } \\
\text { Environmental } \\
\text { Sustainability } \\
\text { The ASEAN } \\
\text { Economic } \\
\text { Community } \\
\text { Blueprint }\end{array}$ & $\begin{array}{l}\text { The Summit ran with a theme on the One } \\
\text { ASEAN at the Heart of Dynamic Asia and } \\
\text { covered themes on energy, environment, } \\
\text { climate change and sustainable } \\
\text { development. The leaders also endorsed } \\
\text { the ASEAN Economic Community } \\
\text { Blueprint which will help to actualize the } \\
\text { concrete targets for establishing a single } \\
\text { market and production base of ASEAN in } \\
2015.40\end{array}$ \\
\hline $15^{\text {th }}$ & $\begin{array}{c}\text { Oct. 23-25, } \\
2009\end{array}$ & $\begin{array}{l}\text { Hua Hin, } \\
\text { Thailand }\end{array}$ & $\begin{array}{l}\text { Cha-am Hua Hin } \\
\text { Statement on } \\
\text { East Asia } \\
\text { Summit (EAS) } \\
\text { Disaster } \\
\text { Management }\end{array}$ & $\begin{array}{l}\text { The Summit involved the Leaders of } \\
\text { ASEAN League of Nations together with } \\
\text { their dialogue partners from People's } \\
\text { Republic of China, Japan, South Korea, } \\
\text { India, Australia and New Zealand.41 }\end{array}$ \\
\hline $16^{\text {th }}$ & $\begin{array}{c}\text { Apr. 8-9, } \\
2010\end{array}$ & $\begin{array}{c}\text { Hanoi, } \\
\text { Vietnam }\end{array}$ & $\begin{array}{l}\text { ASEAN Leaders' } \\
\text { Statement on } \\
\text { Sustained } \\
\text { Recovery and } \\
\text { Development }\end{array}$ & $\begin{array}{l}\text { This Summit addressed the theme of } \\
\text { Towards the ASEAN Community: from } \\
\text { Vision to Action. } 42\end{array}$ \\
\hline
\end{tabular}

39 For details, see Twelfth ASEAN Summit, available at http://www.asean.org/news/item/twelfth-asean-summit-cebuphilippines-9-15-january-2007 (last visited on Nov. 1, 2012).

40 For details, see Thirteenth ASEAN Summit, available at http http://www.asean.org/news/item/thirteenth-aseansummit-singapore-18-22-november-2007 (last visited on Nov. 1, 2012).

41 For details, see Fifteenth ASEAN Summit, available at http://www.asean.org/news/item/fifteenth-asean-summit-chaam-hua-hin-thailand-23-25-october-2009 (last visited on Nov. 1, 2012).

42 For details, see Sixteenth ASEAN Summit, available at http://www.asean.org/news/item/sixteenth-asean-summit-hanoi-8-9-april-2010 (last visited on Nov. 1, 2012). 


\begin{tabular}{|c|c|c|c|c|}
\hline $17^{\text {th }}$ & $\begin{array}{c}\text { Oct. 28-30, } \\
2010\end{array}$ & $\begin{array}{c}\text { Hanoi, } \\
\text { Vietnam }\end{array}$ & $\begin{array}{l}\text { Master Plan on } \\
\text { ASEAN } \\
\text { Connectivity }\end{array}$ & $\begin{array}{l}\text { Stressing on connectivity between ASEAN } \\
\text { countries as the core of ASEAN community } \\
\text { cooperation with regard to the } \\
\text { competitiveness of ASEAN, how ASEAN } \\
\text { shall survive in the global world, in } \\
\text { reducing development gap, encountering } \\
\text { challenges, and its immediate } \\
\text { implementation in 2011-2015.43 }\end{array}$ \\
\hline $18^{\text {th }}$ & $\begin{array}{c}\text { May 7-8, } \\
2011\end{array}$ & $\begin{array}{c}\text { Jakarta, } \\
\text { Indonesia }\end{array}$ & $\begin{array}{l}\text { ASEAN Leader' } \\
\text { Statement on } \\
\text { ASEAN } \\
\text { Community } \\
\text { in a Global } \\
\text { Community of } \\
\text { Nations } 44\end{array}$ & $\begin{array}{l}\text { The statement covers the expectation of } \\
\text { ASEAN Leaders of the better role of ASEAN } \\
\text { in the life of the global community. } 45\end{array}$ \\
\hline $19^{\text {th }}$ & $\begin{array}{c}\text { Nov. } \\
14-19,2011\end{array}$ & $\begin{array}{c}\text { Bali, } \\
\text { Indonesia }\end{array}$ & $\begin{array}{l}\text { Declaration on } \\
\text { ASEAN } \\
\text { Community } \\
\text { in a Global } \\
\text { Community of } \\
\text { Nations (Bali } \\
\text { Concord III) } 46\end{array}$ & $\begin{array}{l}\text { The declaration covers three field of } \\
\text { cooperation: Political-Security, Economic, } \\
\text { and Social-cultural cooperation. } 47\end{array}$ \\
\hline
\end{tabular}

Source: Compiled by the author.

43 For details, see Seventeenth ASEAN Summit, available at http://www.asean.org/news/item/seventeenth-aseansummit-28-30-october-2010 (last visited on Nov. 1, 2012). The concept of ASEAN connectivity include the following three elements: (1) physical infrastructure development (physical connectivity); (2) effective institutions, mechanisms and processes (institutional connectivity); and (3) empowered people (people-to-people connectivity). See Master Plan on ASEAN Connectivity, available at http://www.mfa.go.th/asean/contents/files/asean-article-20120410-224815712575.pdf (last visited on Nov. 1, 2012).

44 The following two documents were adopted in the Summit: (1) ASEAN Leaders' Statement on the Establishment of ASEAN Institute for Peace and Reconciliation, available at http://cil.nus.edu.sg/rp/pdf/2011\%20ASEAN\% 20Leaders\%20Joint\%20Statement\%20on\%20Estb\%20of\%20an\%20ASEAN\%20Institute\%20for\%20Peace\%20and\%20Reco nciliation-pdf.pdf (last visited on Nov. 1, 2012); and (2) ASEAN Leaders' Statement on Enhancing Cooperation against Trafficking in Person in South East Asia, available at http://www.asean.org/archive/Joint_Statement_TIP.pdf (last visited on Nov. 1, 2012).

45 For details, see Eighteenth ASEAN Summit, available at http://www.asean.org/news/item/eighteenth-asean-summitjakarta-7-8-may-2011 (last visited on Nov. 1, 2012).

46 The Summit has adopted the nine documents as follows: (1) Declaration on ASEAN Connectivity; (2) Declaration on the Principles for Mutually Beneficial Relations; (3) Declaration on ASEAN-Japan Plan of Action 2011-2015; (4) Joint Declaration for Enhancing ASEAN-Japan Strategic Partnership for Prospering Together; (5) ASEAN Leaders' Statement on Cooperation in Flood Prevention, Mitigation, Relief, Recovery and Rehabilitation; (6) Declaration on ASEAN Community in a Global Community of Nations (Bali Concord III); (7) Declaration on the Enhancement of 
All soft legal documents adopted through the Summits are backed up by numbers of legal and technical documents including the 1977 Preferential Trade Agreement ("PTA"),48 the 1992 ASEAN Free Trade Area ("AFTA"),49 the 1995 ASEAN Framework Agreement on Services ("AFAS"),50 the 1998 ASEAN Investment Area ("AIA"),51 and the 1998 Hanoi Plan of Action ("HPA").52 All these meetings and legal documents share excellent ideas on the success of negotiation and harmonize the ideological tension among the ASEAN countries, instead of bringing military conflict in the ASEAN community. However, all these legal documents have failed to bring the idea of ASEAN cooperation into the real world of the ASEAN people.

Ideological tension in the ASEAN law-making process flows out from the real needs and interests of the ASEAN nations. Different environmental, historical, cultural, and political background exist among the ASEAN countries, which produces different needs and interests. The practical view of the ASEAN life shows that the ASEAN countries rely very much on their pragmatic needs and interest; they suddenly force them to share the world's dominant ideologies, such as pragmatism, capitalism, and philanthrocapitalism as they deal closely with the international economic development program organized by International Monetary Fund ("IMF") and the World Bank ("WB").53 Under all schemes of loan, grant, donation, banking and any other financial programs, investment and privatization, including any domestic and community

the Role and Participation of Person with Disabilities in the ASEAN Community; (8) ASEAN Leaders' Statement on Climate Change; and (9) Declaration of Commitment on Getting To Zero New HIV Infection, Discrimination, AIDSRelated Death. See Nineteenth ASEAN Summit, available at http://www.asean.org/news/item/asean-structure-aseansummit (last visited on Nov. 1, 2012).

47 The political-security cooperation covers the following: (1) peace, security, and stability; and (2) political development. The economic cooperation covers the following: (1) economic integration; (2) economic stability; (3) economic development. The Social-cultural cooperation covers: (1) disaster management; (2) sustainable development, environment, and climate change; (3) health, science and technology, education, human resources, culture, and the high quality of life. For details, see Nineteenth ASEAN Summit, available at http://www.asean.org/news/item/aseanstructure-asean-summit (last visited on Nov. 1, 2012).

48 For details, see Agreement on ASEAN Preferential Trade Arrangement, available at http://www.aseansec.org/ 1376.htm (last visited on Nov. 1, 2012).

49 For details, see ASEAN Free Trade Area, available at http://www.worldtradelaw.net/fta/agreements/afta.pdf last visited on Nov. 1, 2012).

50 For details, see ASEAN Framework Agreement on Services, available at http://insaps.org/page.php?id=NDAz (last visited on Nov. 1, 2012).

51 For details, see ASEAN Investment Area, available at http://www.aseansec.org/6480.htm (last visited on Oct. 13, 2012).

52 For details, see Hanoi Plan of Action, available at http://www.mofa.go.jp/policy/economy/apec/2006/action.pdf (last visited on Nov. 1, 2012).

53 D. Kennedy, Three Globalizations of Law and Legal Thought: 1850-2000, in The NEW LAW AND EconomiC Development: A Critical Appraisal 57-58 (D. Trubek \& A. Santos eds. 2006). See also M. Trebilcock \& R. Daniels, Rule of Law Reform and Development: Charting the Fragile Path of Progress 1 (2008). 
economic development program, the ASEAN countries share all alien values contained in an economic development program organized by the supreme rulers of the world's economic development program. 54 Those values force each ASEAN State, usually out of their consciousness, into their domestic and community's values system through any of their economic development programs. Under this scheme, each ASEAN State shares all values flowing out from those ideologies and forces them to think and behave in conformity with the values, more capitalistically and pragmatically. The unconscious absorbing of those ideologies creates a free and more powerful work of the ideology influencing the State's way of thinking and behavior.

Under capitalism, philanthrocapitalism, and pragmatism, all ASEAN States drive into their inner world shifting on their own needs and interests which at the end bring them into similar targets for fulfilling their domestic needs. 55 All community idealism drops simply into their domestic business. The ASEAN member States easily achieve any agreement they wish to adopt in terms of their community business, but then simply drop into doubt, distrust, and ignorance. Considering this fact, harmonizing ideological tension may not be limited to the expressed ideological tension, but more to the real ideological tension backstage. Not sharing the same needs, interests, and targets of domestic development is a fundamental cause of ideological tension among the ASEAN countries.

For solving the problem of their future policy process, they need to perform the following policy techniques. First, they need to identify, objectively, clearly and technically, each of their actual environments, culture, historical, economic, and political backgrounds, including their individual and common needs and interest, in order to get a more objective, clear and technical concept for their cooperation. Subjective and general input would result in non-executable concept of their cooperation. Second, they

54 Almost all developing countries, including ASEAN countries, share the same bad experiences of absorbing alien values into their community, such as Iraq, Chile, Rwanda, and Argentine. For Iraq and Chile experiences, see D. Harvey, Neoliberalisme dan Restorasi Kelas Kapitalis 9-20 (2009). For Rwanda, see D. Goldsbrough, T. Leeming \& K. Christiansen, IMF Programs and Health Spending: Case Study of Rwanda (2007), available at http://www.cgdev.org/doc/IMF/Rwanda.pdf (last visited on Nov. 1, 2012). For Argentine, see J. Hornbeck, The Argentine Financial Crisis: A Chronology of Events, CRS Report (2002), available at http://www.docstoc.com/ docs/53020912/CRS (last visited on Nov. 1, 2012). For Indonesia, see J. Winters, Dosa-Dosa Politik ORde Baru 50 (1999). For East Asia, see J. STiglitZ, GLobalization And Its Discontents 89 (2002). For common experience of most developing countries in absorbing the value of the Rule of Law, see Kennedy, supra note 53, at 253. See also Trebilcock \& Daniels, supra note 53.

55 The latest version of the ASEAN utopian cooperation legal framework is noticeable in the "Phnom Penh Declaration 2012: One Community, One Destiny." For details, see ASEAN Legal Instruments, available at http://www.aseansec.org/ 16588.htm (last visited on Nov. 1, 2012). All Speeches of Secretary General of the ASEAN, R. Severino Jr., reflect the three main interests battled through the ASEAN cooperation: (1) the capitalist interest; (2) the government as an instrument of the political party interest; and (3) the capitalist agencies (the broker), individual or group, who gain benefit from the cooperation. See R. SEvERINo JR., ASEAN RISES to THE CHALLENGE (1999). 
have to draw up the concept of their cooperation in the more objective and clear way in order to get a more definite and fair concept for their policy basis. The unclear and subjective concept of policy would result in a vague and dogmatic structure and substance of the policy. Third, they have to behave in a more honest and strong trusting manner with each other in expressing each of their domestic and community needs and interests in order to set a strong commitment for the future performance of their cooperation. Dishonesty and distrust between the actors of the cooperation would result in doubt, slowness, and perhaps failure of cooperation. For the better performance of ASEAN policies, the community members need to remove doubt and distrust. Fourth, the member States need to be sure that the ASEAN community cooperation has been properly based on the new contextual policy approach where community expectation is the prime basis and orientation of the cooperation. Any policy which does not rely on community expectation is an illusion. All policy setting shall be started from community needs and interest mapping and all policy shall be a direct answer to the community needs and interest. Fifth, the member States have to be sure that they have posed their self as an agent of the community for defending the community identity from any attack of outside ideological values for the reason of its position as the mark of existence of the ASEAN community or as an economic power. All those things are prerequisites for solving ideological tension as an obstacle hampering the operation of the ASEAN laws. 56

\section{The Facts of Ideological Influence}

The influence of ideological tension against the legal products of ASEAN cooperation may not be observed. There are three facts that indicate the influence of the ideological tension over the work of ASEAN laws: (1) the slowness of the performance of the ASEAN cooperation; (2) the failure of ASEAN cooperation to bring the benefits of cooperation to the ASEAN people; and (3) the focus of the ASEAN countries from merely culture and economic to military issues, which recognizes a powerful pressure of external values. All these facts demonstrate the influence of doubt among the ASEAN countries with regard to the future position of the ASEAN community. These attitudes are rooted in the similar inner world needs and interest as well as the capitalistic and pragmatic views of each State. 57

\footnotetext{
56 All these policy techniques are developed under the policy analyses model of McDougal's Policy-Oriented approach to legal study. See McDougal, supra note 5, at 58-59.

57 Tension between individual and the common interest of State has been one of the most common and classical issue
} 


\section{The Proposed Approach for Legislation}

The slow performance of ASEAN cooperation is due to the real pragmatic and capitalistic vision of each ASEAN country's law and ideology. Hence, it may be only solved through an ideological approach to the ASEAN legal process. There are four subdivisions of law process in general, including: (a) the law-making process; (b) the lawactuating process; (c) the law-implementing process; and (d) the law-enforcement process. 58 The improper function of the ASEAN law is closely connected with (a) and (b), while (c) and (d) are mostly depend on the existence of (a) and (b). The law-making process of the ASEAN is based on a very utopian vision of most member States. It does not exist in the daily life of the ASEAN community, but is greatly influenced by the myth of regionalism, such as the European Union and other trade blocs which rely on their well tested experience along their national, cultural and political history.59

The ASEAN has its own environmental, cultural, historical, and political background as a context of their law-making process. For this reason, the ASEAN may seriously identify the environmental, cultural, historical, and political background, which shall firmly include the strict dictating and controlling position of the IMF and the World Bank. The Association shall also accurately measure the depth of influence of the capitalistic and pragmatic values against their domestic and community affairs. Based on all these contextual requirements they may be able to recover the improper function of their law towards their cooperation. The policy-oriented approach to legal study, which includes contextual and constructive perspective, may be suitable for solving the ideological tension in the ASEAN law-making process. 60

in the development of international cooperation, both universal and regional cooperation. See R. Keohane, The Theory of Hegemonic Stability and Change in International Economic Regimes 1967-1977, in INTERNATIONAL POLITICAL ECONOMY 99 (C. Goddard et al. eds. 2003).

58 Schwarzenberger has introduced the basic idea of the process of law, particularly international law. The process is divided into two divisions of process, i.e. the law creating process and the ascertainment of rules of international law. This idea could be developed into the more comprehensive division of process of law, based on the facts of the most legal systems, i.e. the law-creating process, the law-actuating process, the law-implementing process, and the law-enforcement process. See G. Schwarzenberger, A Manual of InTERnational LaW 27 (1967).

59 L. Henkin et al, International LaW: Cases and Materials 1413 (1987). See also P. Dempsey, Aerial Dogfighting over Europe: The Liberalization of EEC Air Transport, 52 J. AIR L. \& CoM. 617 (1987); M. Plummer, Creating an ASEAN Economic Community: Lessons from the EU and Reflections on the Roadmap, Hew ed., supra note 12.

60 McDougal, supra note 5, at 57. See also L. Wintgens, Legisprudence as a New Theory of Legislation, 19 RATIO JuRIS 1 (2006). 


\section{Harmonizing Values and Strengthening the Power of Law}

The power of law is in accordance with the quality of legal contents, which depends on its confirmation with its context. Most of the ASEAN law is in disaccord with its contextual expectations, including values, environment, culture, history, and politics. The ASEAN people expect direct contact and access to ASEAN trade activities, while the law is more concerned with articulating the free movement of capital, goods, services, and other production factors. The scope of some schemes, like the PTA, 61 AFTA,62 the 1995 Framework Agreement on Services, 63 and the 1998 Investment Area64 were not enough beneficial to the ASEAN people. They work very slowly and have not brought meaningful effects to the life of people. The Indonesian commitment on tourism services is a glaring example which has not been supported by enough infrastructure. 65 Similar examples are existed in various commitments that have been set up by other ASEAN countries. In these cases, the daily life of people is separated from the commitments.

There are two ways to solve this problem. The first way is to revise the strict portion of law to fit it within its context. The second one is to revise only the strict law with full consideration to its context. The revision may be supported by ideological identification and analyses covering various aspects of its sources, including: (a) the value change from the State's intrinsic ideology to capitalism and pragmatism as its new ideologies; (b) the factual existence of environment, culture, history and politics and its influence to each ASEAN State's needs and interests; (c) the identification of the actual or the real needs and interests of each ASEAN country. Aspect (a) is necessary for clarifying each ASEAN State's political vision, needs and interest over the existence of the ASEAN community. Aspect (b) is needed for clarifying the real and factual needs and interests of each ASEAN country. It is important for determining potentials of each country in

For details, see ASEAN Framework Agreement on Services, available at http://www.aseansec.org/6628.htm (last visited on Nov. 1, 2012).

64 For details, see ASEAN Investment Area, available at http://www.aseansec.org/6480.htm (last visited on Nov. 1, 2012).

65 Indonesia has set commitments on tourism services such as hotels. Indonesia has opened the market access for up to $100 \%$ holding of shares by foreign investors, but this is limited to the Eastern Indonesian region. Even though the access has been fully opened, the region has not supported with an equal infrastructure. Hence, this commitment is useless, which bring no benefit to Indonesian people in this particular region. See I. WYASA, HUKUM BISNIS PARIWISATA (Tourism Business Law) (available only in Indonesian) 42 (2003). 
sharing the development of the ASEAN Economic Community ("AEC") and in trading through the ASEAN market any of their production factors and products which is most beneficial to both the State and the Community. Aspect (c) is required for clarifying any real hard law needed for supporting the Community's cooperation, which shall be followed by legal instruments. 66

Strengthening the power of law, from the ideological point of view, is the whole process of context testing and fixing of the legal instruments. Context testing is related to the values, needs and interest contained in the legal instruments based on the community expectation; it means the expectation of the people, in the community over the content and function of the law in response to the actual community needs and interests. 67 Existence and function of any legal instruments shall be tested based on their actual effects to the life of the community members. Content fixing is the reviewing and revising of the legal product based on the result of the context testing, which may include all context components testing, such as values, environment, culture, history, politics, and any other context components as the source of the values, needs, and interest of the people in the community. 68

\section{Conclusion}

Ideological tension among the ASEAN countries is a negative factor in the implementation of the ASEAN laws. It makes the law function improperly and slows down the performance of ASEAN cooperation. Ideological tension is rooted in the common community values of ASEAN countries and the ideological values change in several aspects of community components. The ASEAN community symbol, such as politeness and dishonesty, have resulted in the confusing formulation between the explicated and the implicated values, needs, and interests. The gap has impeded the effective work of the ASEAN law.

\footnotetext{
66 These ways of problem solving are the result of 'context testing' against ASEAN's policies. See McDougal, supra note 5 , at 56-58, 65 .

67 Id.

68 Id., at 56. According to Watson, context or contact to context loss in any development program has been caused by the failure of the policy maker in setting the approach of the development policy. This is mostly caused by the absence of the following: (1) moral theory as a constitutive feature of International Political Economic; (2) historicized conception of economic relations; (3) challenges to all manifestations of a rationalist ontology; (4) theory of social action; (5) the individual from explanatory accounts in the international political economy. In this case it should be the political economy of ASEAN cooperation. See M. WATSOn, Foundation of InTERNATIONAL PoLiTICAL ECONOMY 33-40 (2005).
} 
The ASEAN member State experienced the change of ideological values from each of their intrinsic State ideology into capitalism, philanthrocapitalism, and pragmatism. As has been dictated by the global community, it has released similar needs, interests, political vision, attitudes, and behavior, which ended in the same room of egoistic and individualistic desire for fulfilling their own needs and interests in the sense of using the community and any member State for benefiting and enriching their own. Ideological tension is also influenced by the community components, such as values, environment, culture, history, and political background of each State. This tension may be managed through legal and ideological approach to the ASEAN law. It includes contextual and constructive aspect to legal studies, which shall include contextual and validity tests. 